\title{
27. ORGANIC GEOCHEMISTRY OF MESOZOIC SEDIMENTS FROM DEEP SEA DRILLING PROJECT SITE 330, FALKLAND PLATEAU ${ }^{1}$
}

\author{
Bernd R. T. Simoneit, Institute of Geophysics and Planetary Physics, University of California, Los Angeles
}

\begin{abstract}
Sources of organic matter in Mesozoic sediments from the DSDP Site 330, Falkland Plateau, have been examined. The lipids of a Cretaceous sample are mixed terrigenous and marine, and those of a Jurassic sample are predominantly marine. Kerogens are predominantly oxidized terrigenous detritus, except from an autochthonous marine sample from the middle Jurassic.
\end{abstract}

\section{INTRODUCTION}

The organic matter of various Mesozoic sediments from the Atlantic Ocean has been analyzed (e.g., Simoneit, 1978a, 1978b, 1979, in press [a], Stuermer and Simoneit, 1978; Deroo et al., 1978). These data have resulted in detailed assessments of the conditions of sedimentation, of the catagenetic maturity of the organic matter, and of the biogenic origins of the organic matter (Simoneit, in press[a]; Deroo et al., 1978). Similar data for the South Atlantic Ocean are sparse; thus it was of interest to examine the samples from DSDP Leg 36 (e.g., Simoneit, in press [a].)

The samples analyzed here are from Site 330 $\left(50^{\circ} 55.19^{\prime} \mathrm{S}, 46^{\circ} 53.00^{\prime} \mathrm{W}\right.$; water depth $\left.2626 \mathrm{~m}\right)$, at the western end of an elongate rise, the Maurice Ewing Bank (Barker et al., 1974), forming the eastern end of the Falkland Plateau.

\section{ANALYTICAL METHODS}

The core samples were freeze-dried and then extracted with toluene and methanol (4:1), using ultrasonication. The extracts for each sample were concentrated on a rotary evaporator and subjected to gas chromatography (GC). The extracts were then treated with diazomethane in ether and subjected to silica-gel thinlayer chromatography (TLC), using methylene chloride as eluent. The bands corresponding to hydrocarbons, esters, and ketones were scraped off the TLC plate after development with iodine vapor, and eluted with ether or ethyl acetate. The hydrocarbon and combined ester and ketone fractions were subjected to GC and combined GC and mass spectrometric (MS) analyses.

The GC analyses were carried out on a HewlettPackard model 5830 gas chromatograph, using a 16 meter by $0.25 \mathrm{~mm}$ stainless steel Scott column coated with OV-101, programmed from 110 to $280^{\circ} \mathrm{C}$ at $4^{\circ} \mathrm{C}$ per minute, using $\mathrm{He}$ carrier gas at a flow rate of 3 $\mathrm{ml} / \mathrm{min}$.

\footnotetext{
${ }^{1}$ Contribution No. 1919 from the Institute of Geophysics and Planetary Physics, University of California, Los Angeles. (This chapter was included in this volume for publication convenience.)
}

The GC/MS analyses were carried out on a Finnigan model 4000 quadruple mass spectrometer interfaced directly to a Finnigan model 9610 gas chromatograph equipped with a 30 meter by $0.25 \mathrm{~mm}$ glass capillary column coated with OV-101. The GC conditions for the GC/MS analyses were like those for the analytical GC system. Mass-spectrometry data were recorded and processed by a Finnigan-Incos model 2300 data system.

Analyses of stable carbon isotopes were carried out by the methodology described by Kaplan et al. (1970), using the Chicago PDB as reference standard.

\section{RESULTS AND INTERPRETATION}

Sample descriptions and results of the carbon, lipid, and kerogen analyses are in Table 1 . The organiccarbon content of the sapropelic claystones is high, and the lipid yield is low. An evaluation of the petroleum potential of these sediments has been presented (Comer and Littlejohn, 1976), in which hydrocarbons and kerogens were analyzed.

Concentrations of various homologous-compound series in the lipid fractions are given in Figure 1. The $n$-alkanes for Sample 330-4-2, 120-126 cm (Neocomian) exhibit a bimodal distribution, ranging from $n-\mathrm{C}_{13}$ to $n$ - $\mathrm{C}_{35}$, with maxima at $\mathrm{C}_{19}$ and $\mathrm{C}_{31}$ and a strong oddcarbon-number predominance (Figure 1A). The homologs $>n-\mathrm{C}_{25}$ are derived from higher-plant wax, and those $<n-\mathrm{C}_{21}$ are indicative of a bacterial origin ( $\mathrm{Si}$ moneit, 1979c). The presence of significant amounts of $n$-alkylcyclohexanes, $\mathrm{C}_{n} \mathrm{H}_{2 n}$, with carbon numbers ranging from 13 to 25 , and a maximum at 19 (Figure 1C), is further evidence for bacterial lipid.residues. The pristane/phytane ratio is 0.5 , and the presence of elemental sulfur indicates euxinic conditions of sedimentation (Didyk et al., 1978), in agreement with preliminary findings (Barker et al., 1974). The $n$-fatty acids exhibit a bimodal distribution over the range from $n-\mathrm{C}_{12}$ to $n-\mathrm{C}_{32}$, and a strong even-carbon-number predominance, with maxima at $n-\mathrm{C}_{16}$ and $n-\mathrm{C}_{28}$ (Figure 1E). The maximum at $n-\mathrm{C}_{28}$ fatty acid, when considered with the maximum at $n-C_{31}$ for the $n$-alkanes, indicates a higher-plant-wax origin (Simoneit, in press[b]). The $n$-fatty acids $<n-\mathrm{C}_{20}$ 
TABLE 1

Sample Descriptions and Results of Carbon, Lipid, and Kerogen Analyses

\begin{tabular}{|c|c|c|c|c|c|c|c|c|c|c|c|c|c|c|c|c|c|c|c|}
\hline \multirow[b]{3}{*}{$\begin{array}{c}\text { Sample } \\
\text { (Interval in cm) }\end{array}$} & \multirow{3}{*}{$\begin{array}{l}\text { Sub- } \\
\text { Depth } \\
\text { (m) }\end{array}$} & \multirow[b]{3}{*}{$\begin{array}{c}\text { Geologic } \\
\text { Age }\end{array}$} & \multirow[b]{3}{*}{ Lithology } & \multirow{2}{*}{\multicolumn{3}{|c|}{ Carbon $^{a}$}} & \multirow{2}{*}{\multicolumn{3}{|c|}{$n$-alkanes }} & \multirow{2}{*}{\multicolumn{3}{|c|}{$\begin{array}{l}\text { Lipid Yields } \\
n-f a t t y \text { acids }\end{array}$}} & \multirow{2}{*}{\multicolumn{3}{|c|}{ n-methylketones }} & \multirow[b]{3}{*}{$\mathrm{Pt} / \mathrm{Pl}_{1} \mathrm{~d}$} & \multirow[b]{3}{*}{ Perylene } & \multirow{2}{*}{\multicolumn{2}{|c|}{ Kerogen }} \\
\hline & & & & & & & & & & & & & & & & & & & \\
\hline & & & & $\begin{array}{l}\text { Total } \\
(\%)\end{array}$ & $\begin{array}{l}\text { Org. } \\
(\%)\end{array}$ & $\underset{(\%)}{\mathrm{CaCO}_{3}}$ & $\begin{array}{l}\text { Total } \\
(\mu \mathrm{g} / \mathrm{g})\end{array}$ & CPIb & Max.c & $\begin{array}{l}\text { Total } \\
(\mu g / g)\end{array}$ & $\mathrm{CPJ} \mathrm{b}$ & Max. ${ }^{\mathrm{C}}$ & $\begin{array}{l}\text { Total } \\
(\mu g / g)\end{array}$ & $\mathrm{CPIb}^{\mathrm{b}}$ & Max. ${ }^{c}$ & & & $\mathrm{H} / \mathrm{Ca}$ & $\begin{array}{l}{ }^{513 \mathrm{C}} \\
\left(\% \%_{\infty}\right)^{\mathrm{e}}\end{array}$ \\
\hline $330-4-2,120-126$ & 274.2 & $\begin{array}{l}\text { Cret. } \\
\text { (Neocom.) }\end{array}$ & $\begin{array}{l}\text { Gray } \\
\text { sapropelic } \\
\text { claystone }\end{array}$ & 3.64 & 3.25 & 3 & 3.5 & 1.86 & $\underline{19.31}$ & 4.0 & 7.3 & $\underline{16,28}$ & 0.4 & 0.7 & 16 & 0.5 & 0 & 1.17 & -26.7 \\
\hline $330-5-2,57-61$ & 302.1 & $\begin{array}{l}\text { L. Jur. } \\
\text { (Oxf.- } \\
\text { Kimm.) }\end{array}$ & $\begin{array}{l}\text { Gray } \\
\text { sapropelic } \\
\text { claystone }\end{array}$ & 4.4 & 4.0 & 3 & n.d. & n.d. & n.d. & n.d. & n.d. & n.d. & n.d. & n.d. & n.d. & n.d. & n.d. & 1.11 & -25.5 \\
\hline $330-5-3,29-34$ & 303.3 & $\begin{array}{l}\text { L. Jur. } \\
\text { (Oxf.- } \\
\text { Kimm.) }\end{array}$ & $\begin{array}{l}\text { Gray } \\
\text { sapropelic } \\
\text { claystone }\end{array}$ & 3.5 & 3.2 & 2 & n.d. & n.d. & n.d. & n.d. & n.d. & n.d. & n.d. & n.d. & n.d. & n.d. & n.d. & 1.05 & -25.6 \\
\hline $330-6-6,77-82$ & 317.8 & $\begin{array}{l}\text { L. Jur. } \\
\text { (Oxf.- } \\
\text { Kimm.) }\end{array}$ & $\begin{array}{l}\text { Gray } \\
\text { sapropelic } \\
\text { claystone }\end{array}$ & 4.6 & 4.4 & 2 & n.d. & n.d. & n.d. & n.d. & n.d. & n.d. & n.d. & n.d. & n.d. & n.d. & n.d. & 1.15 & -25.1 \\
\hline $330-10-1,98-102$ & 405.5 & L Jur. & $\begin{array}{l}\text { Olive } \\
\text { sapropelic } \\
\text { claystone }\end{array}$ & 3.12 & 3.1 & 0 & 25 & 1.56 & $\frac{17,22,}{29}$ & 8 & 3.10 & 16.24 & 1.0 & 0.9 & $\underline{11} .16$ & 0.8 & 0 & 1.20 & -27.3 \\
\hline $330-14-4,127-136$ & 524.3 & M. Jur. & $\begin{array}{l}\text { Olive gray } \\
\text { clayey silt }\end{array}$ & 1.87 & 1.8 & 0 & n.d. & n.d. & n.d. & n.d. & n.d. & n.d. & n.d. & n.d. & n.d. & n.d. & n.d. & 1.18 & -24.1 \\
\hline
\end{tabular}

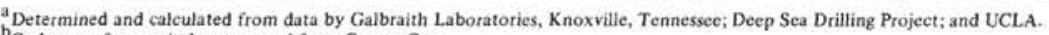

${ }^{b}$ Carbon preference index, summed from $\mathrm{C}_{10}$ to $\mathrm{C}_{35}$.

The dominant homolog is underscored.

Pristine-phytane ratio.

${ }^{\mathrm{e}}$ Compared to Chicago PDB standard.
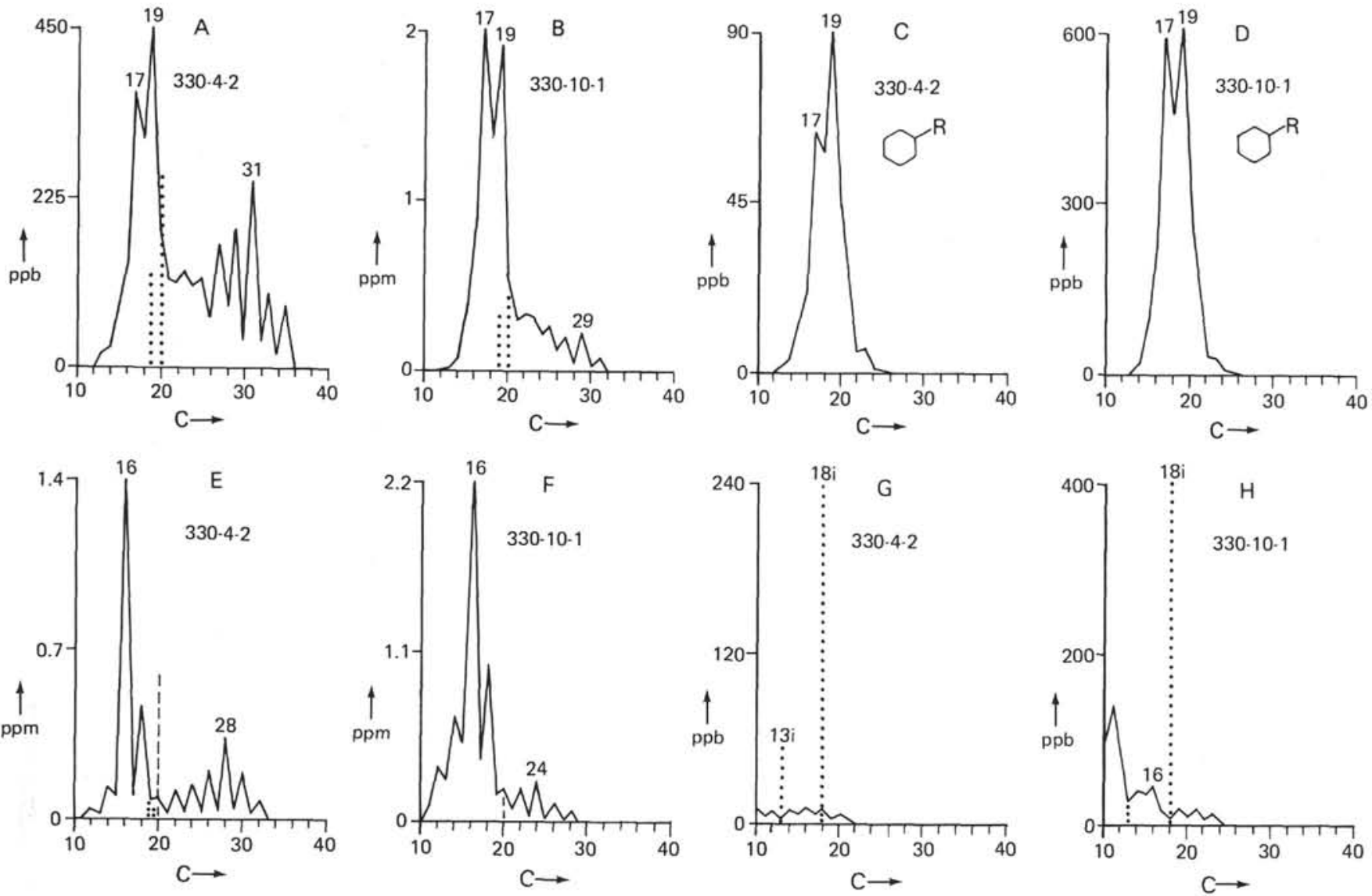

Figure 1. Concentrations of various lipid components: (A) and (B), n-alkanes; (C) and (D), n-alkylcyclohexanes; (E) and $(\mathrm{F}), \mathrm{n}$-fatty acids; $(\mathrm{G})$ and $(\mathrm{H}), \mathrm{n}$-alkane-2-ones. Isoprenoids shown by dotted lines, dehydroabietic acid by dashed lines.

are most likely marine and autochthonous (Simoneit, in press[b]). A significant amount of dehydroabietic acid (structure I) is also present, indicating an allochthonous influx from resinous higher plants (Simoneit, 1977).
The ketones consist predominantly of 6,10,14-trimethylpentadecan-2-one, 6,10-dimethylundecan-2-one and $n$-alkan-2-ones ranging from $C_{10}$ to $C_{21}$ with an even-carbon-number predominance (Figure $1 \mathrm{G}$ ). These 
compounds are probably products of microbial degradation of phytol and microbial lipids (Simoneit, 1973 , in press[b]).

The $n$-alkanes in Sample 330-10-1, 98-102 cm (Upper Jurassic) exhibit an essentially unimodal distribution, ranging from $n-\mathrm{C}_{13}$ to $n-\mathrm{C}_{31}$, with $n-\mathrm{C}_{17}$ and $n-\mathrm{C}_{19}$ dominant (and minor dominance $>n-\mathrm{C}_{25}$ showing a strong odd-carbon-number predominance) (Figure 1B). This indicates a minor influx of higher-plant wax and a predominantly bacterial lipid residue, which is further substantiated by the presence of the alkylcyclohexanes (Figure 1D). The pristane/phytane ratio is 0.8 ; this and the presence of elemental sulfur may indicate partially euxinic conditions of sedimentation (Didyk et al., 1978). The $n$-fatty acids exhibit a bimodal distribution, with a maximum at $n-\mathrm{C}_{16}$ and a lesser one at $n-\mathrm{C}_{24}$, and show a strong even-carbon-number predominance (Figure 1F). These acids are primarily autochthonous microbial products, with a minor allochthonous influx from higher-plant wax. The presence of dehydroabietic acid (I) indicates a contribution from resinous plants (Simoneit, 1977b). The ketones consist of mainly 6,10,14-trimethylpendecan-2-one; 6,10-dimethylundecan-2-one; and $n$-alkan-2-ones ranging from $\mathrm{C}_{10}$ to $\mathrm{C}_{25}$ with a strong odd-carbon-number predominance (Figure $1 \mathrm{H}$ ). These compounds are probably products of microbial degradation of phytol and microbial lipids (Simoneit, 1973, in press[b]).

Perylene, a possible terrigenous marker preserved under anaerobic conditions of sedimentation (Didyk et al., 1978; Aizenshtat, 1973), was not detected in either sample.

The polycyclic components of the hydrocarbon fractions consist of sesquiterpenoidal, diterpenoidal, triterpenoidal, and steroidal compounds. The sesquiterpenoids comprise cadalene (II), tetrahydrocadalene (probably 5,6,7,8-tetrahydro, III), and a trace of cadinane (IV) in both Samples 330-4-2, 120-126 cm and 330-10-1, 98-102 $\mathrm{cm}$. These compounds may have origined from resinous plants or from autochthonous algae. The diterpenolidal compounds of both samples consist of dehydroabietane (V), retene (VI), dehydroabietin (VII) with another isomer, and simonellite (VIII). These diterpenoids are derived from terrestrial resinous plants (Simoneit, 1977b). The relative concentrations of diterpenoids and triterpenoids (based on the $\mathrm{m} / \mathrm{z} 191$ peak intensity in the GC/MS data and on GC response) are plotted in Figure 2.

The triterpenoids are composed mainly of the hopane series, with minor amounts of the moretanes. The $17 \beta(\mathrm{H}), 21 \beta(\mathrm{H})$ stereomers are predominant over the $17 \alpha(\mathrm{H}), 21 \beta(\mathrm{H})$ isomers, and $17 \beta(\mathrm{H}), 21 \beta(\mathrm{H})$-homohopane (IX, $\mathrm{R}=\mathrm{CH}_{3}$ ) is the major homolog. The hopane series comprises the trisnorhopanes $(X, R=H)$, norhopanes $\left(X, R=\mathrm{C}_{2} \mathrm{H}_{5}\right)$, hopanes $\left(X, R=\mathrm{C}_{3} \mathrm{H}_{7}\right)$, homohopanes (IX, $\mathrm{R}=\mathrm{CH}_{3}$ ), and bishomohopanes (IX, $\mathrm{R}=\mathrm{C}_{2} \mathrm{H}_{5}$ ). The moretane series probably consists of the $17 \beta(\mathrm{H}), 21 \alpha(\mathrm{H})$ stereomers and ranges from $\mathrm{C}_{30}$ to $\mathrm{C}_{32}$. No triterpenes were detected. These triterpanes are probably autochthonous, derived from the diagenetic products of bacteriohopanepolyols (Rohmer,
1975). The dominance of the $17 \beta(\mathrm{H})$ stereochemistry (cf. ratios $<1.0$ in Table 2), indicates the geologic immaturity of these triterpenoids (Dastillung and Albrecht, 1976; Simoneit and Kaplan, in press). Similar triterpane distributions were found for Cretaceous shales from the North Atlantic Ocean (e.g., Simoneit, 1979a,d). Triterpenoidal acids were identified in Sample $330-10-1,98-102 \mathrm{~cm}$ only and consisted of the extended hopanoic acids (XI) ranging from $\mathrm{C}_{31}$ to $\mathrm{C}_{33}$. The $17 \beta(\mathrm{H})$ stereomers are predominant over the $17 \alpha(\mathrm{H})$ stereomers (cf. ratios $<1.0$ in Table 2), indicating that they are also geologically immature.

Significant amounts of steranes are present, and their concentrations are plotted in Figure 3. The $5 \alpha(\mathrm{H})$ isomers (XII) are predominant over the $5 \beta(\mathrm{H})$ series (XIII) (i.e., cholestane $>$ coprostane) for both samples. The ratios of the cis $(5 \beta)$ to trans $(5 \alpha)$ stereomers are given in Table 2; all are less than 0.6. Ratios for mature source rocks and petroleums have been observed in the range 0.6 to 0.8 (e.g., Seifert and Moldowan, 1978). Cholestane (XII, $\mathrm{R}=\mathrm{H}$ ) is the predominant sterane in Sample 330-4-2, 120-126 cm and 24-ethylcholestane (XII, $\mathrm{R}=\mathrm{C}_{2} \mathrm{H}_{5}$ ) is the major sterane in Sample $330-10-1,95-102 \mathrm{~cm}$. The distribution of the steranes in Sample 330-4-2, 120-126 cm appears to indicate that they are terrigenous; the steranes of Sample 330-10-1, 95-102 cm appear to be autochtonous (Gaskell, 1974; Goad et al., 1972; Rubinstein, 1973); however, the distinction is not very clear.

Contamination from various plasticizers and lubricants is minor and consists primarily of dibutyl and dioctyl phthalates, and dibutyl esters of dicarboxylic acids from the core tubes (Simoneit, 1975).

The kerogen was isolated from the sediments using the procedure of Stuermer et al. (1978) and the ratio $\mathrm{H} / \mathrm{C}$ ranges from 1.05 to 1.20 (Table 1 ; rather aromatic). The $\delta^{13} \mathrm{C}$ values are found in Table 1 . The data for Samples 330-4-2, 120-126 cm; 330-5-3, 29-34 cm; and $330-10-1,98-102 \mathrm{~cm}$ are in the range typical of terrigenous material. The material in Sample 330-14-4, $127-136 \mathrm{~cm}$ is marine. If both the $\mathrm{H} / \mathrm{C}$ and $\delta^{13} \mathrm{C}$ data are considered, this kerogen appears to be oxidized terrigenous detritus which was redeposited at Site 330. This is corroborated by the content of terrestrial pollen and spores (Hedlund and Beju, 1976).

\section{CONCLUSIONS}

The lipids of Sample 330-4-2, 120-126 cm (Cretaceous) are of mixed origin (predominantly marine, with some terrigenous influx), whereas the lipids of Sample 330-10-1, 98-102 cm (Jurassic) are predominantly marine. This is indicated by the distributions of the $n$-fatty acids, alkylcyclohexanes, $n$-alkan-2-ones, and molecular markers such as diterpenoids, sesquiterpenoids, triterpenoids, and steroids.

The kerogens appear to be composed primarily of oxidized terrigenous detritus (low $\mathrm{H} / \mathrm{C}$ values and $\delta^{13} \mathrm{C}$ $<-25 \%$ ), except for Sample 330-14-4, 127-136 cm, which is autochthonous marine. The conditions of sedimentation were anaerobic; there probably was an influx of oxidized kerogen from terrestrial areas, coupled with 

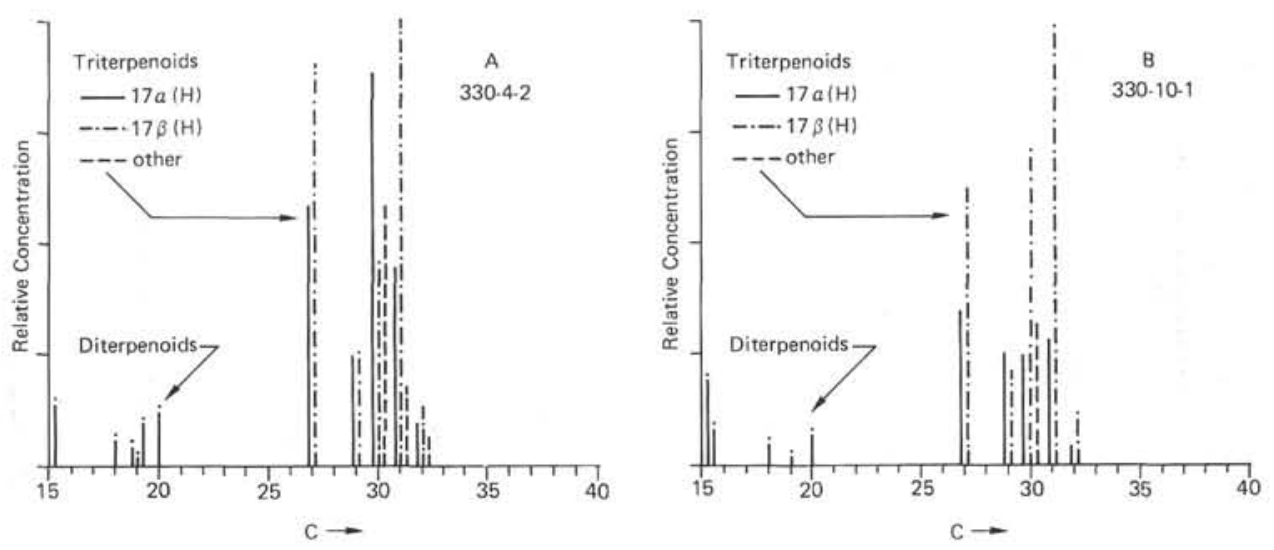

Figure 2. Relative concentrations of diterpenoids and triterpenoids.

TABLE 2

Stereomeric Ratios for Triterpanes and Steranes ${ }^{\mathrm{a}}$

\begin{tabular}{lccccccc}
\hline $\begin{array}{c}\text { Sample } \\
\text { (Interval in cm) }\end{array}$ & $\mathrm{C}_{27}$ & $\mathrm{C}_{28}$ & $\mathrm{C}_{29}$ & $\mathrm{C}_{30}$ & $\mathrm{C}_{31}$ & $\mathrm{C}_{32}$ & $\mathrm{C}_{33}$ \\
\hline \multicolumn{7}{c}{ Triterpanes: } & $17 \alpha(\mathrm{H}) / 17 \beta(\mathrm{H})$ \\
$330-4-2,120-126$ & 0.66 & - & 0.96 & 1.90 & 0.44 & 0.83 & - \\
$330-10-1,98-102$ & 0.55 & - & 1.25 & 0.36 & 0.28 & 0.33 & -
\end{tabular}

Triterpenoid Acids: $17 \alpha(\mathrm{H}) / 17 \beta(\mathrm{H})$

\begin{tabular}{cccccccc}
$330-10-1,95-102$ & - & - & - & - & 0.50 & 0.55 & 0.67 \\
\multicolumn{8}{c}{ Steranes: $5 \beta(\mathrm{H}) / 5 \alpha(\mathrm{H})$} \\
$330-4-2,120-126$ & 0.56 & 0.56 & 0.56 & 0.58 & - & - & - \\
$330-10-1,95-102$ & 0.40 & 0.45 & 0.42 & - & - & - & - \\
\hline
\end{tabular}

apetermined by integration of peaks in the respective m/z 191 and $\mathrm{m} / \mathrm{z}$ 217 mass chromatograms.

some influx of terrigenous lipids for Sample 330-4-2, $120-126 \mathrm{~cm}$, and autochthonous production of lipids. These inferences are in agreement with the description of the sedimentary record at this site (Barker et al., 1974) and other areas (Thiede and van Andel, 1977; Schlanger and Jenkyns, 1976).

\section{ACKNOWLEDGMENTS}

I thank the staff of the Deep Sea Drilling Project and the National Science Foundation for making the core samples available, Ms. Monica A. Mazurek for technical assistance, Mr. E. Ruth for GC/MS data acquisition, Mr. D. Winter for stable-carbon-isotope data, and Dr. P. T. Crisp for manuscript review. Partial financial assistance from the department of Energy and Bureau of Land Management (Contract Number EY-76-S-03-0034, P.A. 134) is gratefully acknowledged.

\section{REFERENCES}

Aizenshtat, Z., 1973. Perylene and its geochemical significance. Geochim. Cosmochim. Acta, 37, 559-567.

Barker, P. F., Dalziel, W. D., Elliott, D. H., von der Borch, C. C., Thompson, R. W., Plafker, G., Tjalsma, R. C., Wise, S. W., Jr., Dinkelman, M. G., Gombos, A. M., Jr., Lonardi, A., and Tarney, J., 1974. South Atlantic Leg 36. Geotimes, 19 (11), 16-18.

Comer, J. B., and Littlejohn, R., 1976. Content, composition and thermal history of organic matter in Mesozoic sedi- ments, Falkland Plateau. In Barker, P. F., Dalziel, I. W. D., et al, Init. Repts. DSDP, 36: Washington (U.S. Govt. Printing Office), pp. 941-944.

Dastillung, M., and Albrecht, P., 1976. Molecular test for oil pollution in surface sediments. Mar. Pollution Bull., 7, $13-15$.

Deroo, G., Herbin, J. P., Roucaché, J., Tissot, B., Albrecht, P., and Schaeffle, J., 1978. Organic geochemistry of some Cretaceous black shales from Sites 367 and 368, Leg 41, Eastern North Atlantic. In Lancelot, Y., Seibold, E., et al., Init. Repts. DSDP, 41: Washington (U.S. Govt. Printing Office), pp. 865-873.

Didyk, B. M., Simoneit, B. R. T., Brassell, S. C. and Eglinton, G., 1978. Geochemical indicators of palaeoenvironmental conditions of sedimentation. Nature, 272, 216-222.

Gaskell, S. J., 1974. The environmental geochemistry of sterols, Ph.D. thesis, University of Bristol, England.

Goad, L. J., Rubinstein, I., and Smith, G., 1972. The sterols of echinoderms. Proc. Royal Soc. Lond., B 180, 223-246.

Hedlund, R. W., and Beju, D., 1976. Stratigraphic palynology of selected Mesozoic samples, DSDP Hole 327A and Site 330. In, Barker, P. F., Dalziel, I. W. D., et al., Init. Repts. DSDP, 36: Washington (U.S. Govt. Printing Office), pp. 817-827.

Kaplan, I. R., Smith, J. W., and Ruth, E., 1970. Carbon and sulfur concentration and isotopic composition in Apollo 11 lunar samples. In Proc. Apollo 11 Lun. Sci. Conf., Geochim. Cosmochim. Acta, Suppl. 1, (Vol 2), pp. 13171329.

Rohmer, M., 1975. Triterpenoides de procaryotes, Ph.D. thesis, l'Université Louis Pasteur de Strasbourg, France.

Rubinstein, I., 1973. A study of marine sterols, Ph.D. thesis, University of Liverpool, England.

Seifert, W. K. and Moldowan, J. M., 1978. Applications of steranes, terpanes and monoaromatics to the maturation, migration and source of crude oils. Geochim. Cosmochim. Acta, 42, 77-95.

Schlanger, S. O., and Jenkyns, H. C., 1976. Cretaceous oceanic anoxic events: causes and consequences. Geol. en Mijnbouw, 55, 179-184.

Simoneit, B. R. T., 1973. Appendix I. Identification of isoprenoidal ketones in Deep Sea Drilling Project core samples and their geochemical significance. In Burns, R. E., Andrews, J. E., et al., Init. Repts. DSDP, 21: Washington (U.S. Govt. Printing Office), pp. 909-923. 1975. Sources of organic matter in oceanic sediments, Ph.D. thesis, University of Bristol, England. 


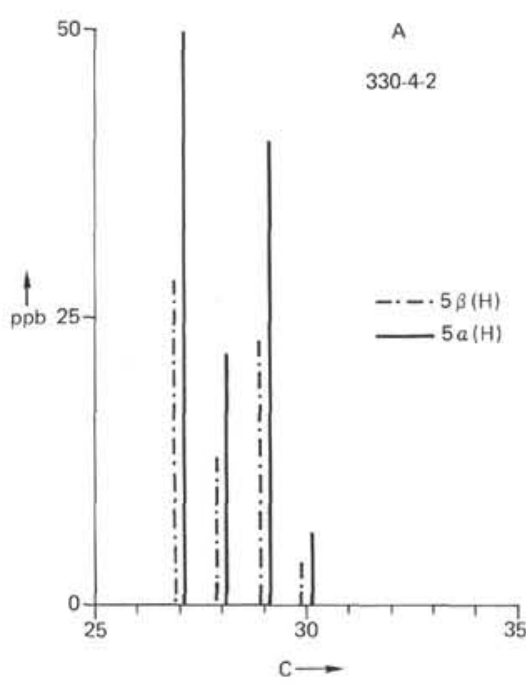

Figure 3. Concentrations of steranes.

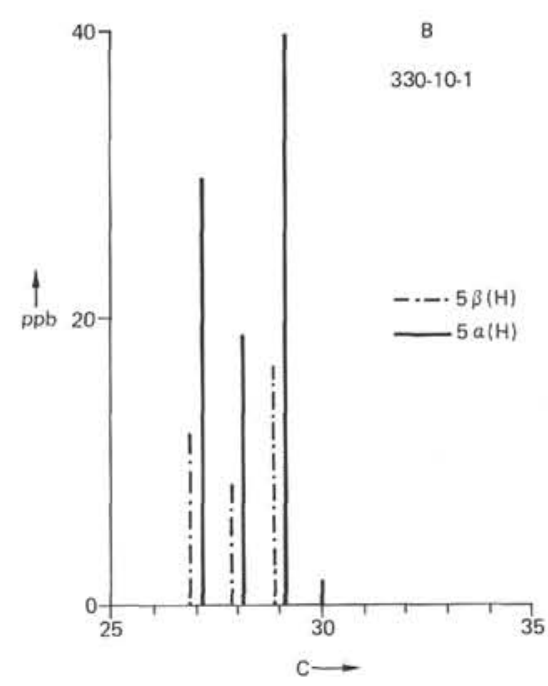

W., (Ed.), Proc. Symp. Org. Geochem. of DSDP Sediments: Princeton (Science Press).

, in press(c). Lipid geochemistry of Cretaceous black shales from the Bay of Biscay, Site 402 and of Eocene mudstone from the Rockall Plateau, Site 404. In Montadert, L., Roberts, D. G., et al., Init. Repts. DSDP, 48: Washington (U.S. Govt. Printing Office).

Simoneit, B. R. T., and Kaplan, I. R., in press. Triterpenoids as molecular markers of paleoseepage in Recent sediments of the Southern California Bight. Mar. Environ. Res.

Stuermer, D. H., Peters, K. E., and Kaplan, I. R., 1978. Source indicators of humic substances and protokerogen: stable isotope ratios, elemental compositions and electron spin resonance spectra. Geochim. Cosmochim. Acta, 42, 989-997.

Stuermer, D. H., and Simoneit, B. R. T., 1978. Varying sources for the lipids and humic substances at Site 391, Blake-Bahama Basin, DSDP Leg 44. In Benson, W. E., Sheridan, R. E., et al., Init. Repts. DSDP, 44: Washington (U.S. Govt. Printing Office), pp. 587-591.

Thiede, J., and van Andel, T. H., 1977. The paleoenvironment of anaerobic sediments in the late Mesozoic South Atlantic Ocean. Earth Planet. Sci. Lett., 33, 301-309. 


\section{APPENDIX}

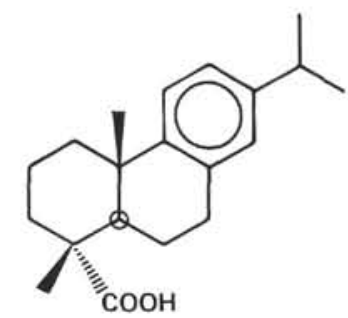

I. Dehydroabietic acid<smiles>CC1CCC2C(C)CCC(C(C)C)C2C1</smiles>

IV. Cadinane<smiles>Cc1ccc2c(C)ccc(C(C)C)c2c1</smiles>

II. Cadalene

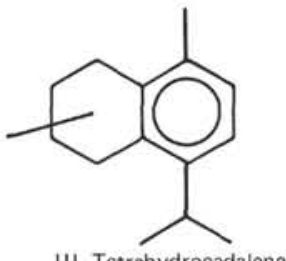

III. Tetrahydrocadalene<smiles>CCC[C@@]1(C)OCCc2cc(C(C)C)ccc21</smiles>

VII. Dehydroabietin<smiles>CC(C)c1ccc2c(c1)CCOC2(C)C</smiles><smiles>CC(C)c1ccc2c(ccc3c([14CH3])cccc32)c1</smiles>

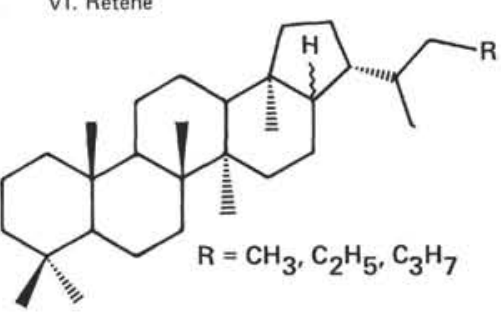

IX. Extended hopanes

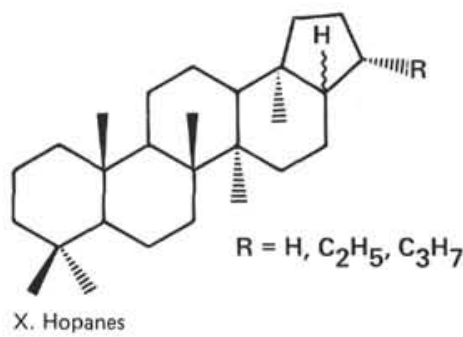

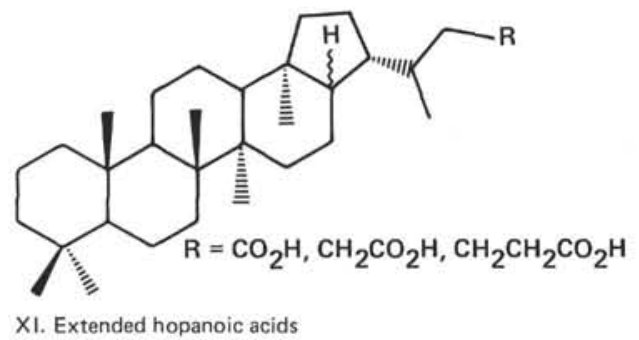

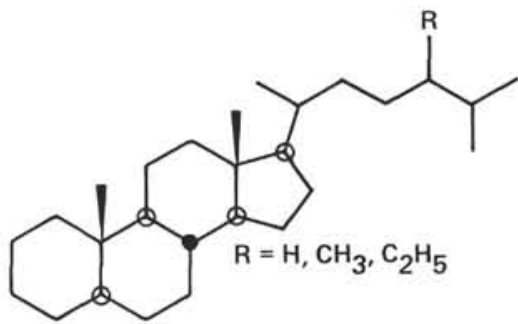

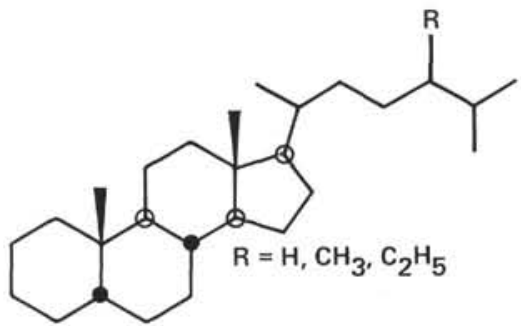

XIII. $5 \beta(H)-$ Steranes 